Click www.researchjournal.co.in/online/subdetail.html to purchase.

INTERNATIONAL JOURNAL OF PLANT PROTECTION

- ISSN-0974-2670 | Visit us : www.researchjournal.co.in

\title{
Variability in pathological characters in Gloeocercospora sorghi isolates from sorghum
}

\author{
Mamta* and Y. Singh
}

Department of Plant Pathology, College of Agriculture, G. B. Pant University of Agriculture and Technology, Pantnagar, U.S. Nagar (Uttarakhand) India

\begin{tabular}{ll} 
ARITCLE INFO \\
\hline Received $: 26.07 .2020$ \\
Revised $: 03.09 .2020$ \\
Accepted $: 18.09 .2020$
\end{tabular}

KEY WORDS :

Sorghum, Gloeocercospora sorghi, Pathogenic variability, PDI, Virulence index

*Corresponding author:

Email : mamtaparth.sarvani@gmail.com

\begin{abstract}
Zonate leaf spot caused by Gloeocercospora sorghi Bain and Edgerton (1943) is one of the most destructive diseases of sorghum in India and Uttarakhand is considered as a hot spot for this disease. The present investigation was carried out to record the pathogenic variability of thirty isolates of Gloeocercospora sorghi on five different lines of sorghum. The G. sorghi isolates differed significantly from each other on the basis of pathological attributes viz., latent period, aggressiveness and virulence index and thus, grouped into three virulence categories. The findings suggest that analysis of variance for latent, aggressiveness, per cent disease intensity (PDI) and virulence index showed that the variations in latent period and virulence disease reaction were attributed more to the isolates and aggressiveness to the host lines than to the isolate $\times$ host line interactions.
\end{abstract}

How to view point the article : Mamta and Singh, Y. (2020). Variability in pathological characters in Gloeocercospora sorghi isolates from sorghum. Internat. J. Plant Protec., 13(2) : 148-155, DOI : 10.15740/HAS/IJPP/13.2/148-155, Copyright@ 2020: Hind Agri-Horticultural Society. 